\title{
PEP-1-GLRX1 protein exhibits anti-inflammatory effects by inhibiting the activation of MAPK and NF- $\kappa B$ pathways in Raw 264.7 cells
}

\author{
Min Jea Shin ${ }^{1, \#}$, Dae Won Kim ${ }^{2, \#}$, Yeon Joo Choi ${ }^{1}$, Hyun Ju Cha ${ }^{1}$, Sung Ho Lee ${ }^{1,3}$, Sunghou Lee ${ }^{4}$, Jinseu Park ${ }^{1}$, \\ Kyu Hyung Han ${ }^{1}$, Won Sik Eum ${ }^{1, *}$ E Soo Young Choi, ${ }^{1, *}$ \\ ${ }^{1}$ Department of Biomedical Science and Research Institute of Bioscience and Biotechnology, Hallym University, Chuncheon 24252, \\ ${ }^{2}$ Department of Biochemistry and Molecular Biology, Research Institute of Oral Sciences, College of Dentistry, Gangneung-Wonju National \\ University, Gangneung 25457, ${ }^{3}$ Genesen Inc., Seoul 06181, ${ }^{4}$ Department of Green Chemical Engineering, Sangmyung University, Cheonan \\ 31066, Korea
}

\begin{abstract}
Glutaredoxin 1 (GLRX1) has been recognized as an important regulator of redox signaling. Although GLRX1 plays an essential role in cell survival as an antioxidant protein, the function of GLRX1 protein in inflammatory response is still under investigation. Therefore, we wanted to know whether transduced PEP-1-GLRX1 protein inhibits lipopolysaccharide (LPS)- and 12-O-tetradecanoyl phorbol-13-acetate (TPA)-induced inflammation. In LPS-exposed Raw 264.7 cells, PEP-1-GLRX1 inhibited cyclooxygenase-2 (COX-2), inducible nitric oxide synthase (iNOS), activation of mitogen activated protein kinases (MAPKs) and nuclear factor-kappaB (NF-kB) expression levels. In a TPA-induced mouse-ear edema model, topically applied PEP-1-GLRX1 transduced into ear tissues and significantly ameliorated ear edema. Our data reveal that PEP-1-GLRX1 attenuates inflammation in vitro and in vivo, suggesting that PEP-1-GLRX1 may be a potential therapeutic protein for inflammatory diseases. [BMB Reports 2020; 53(2): 106-111]
\end{abstract}

\section{INTRODUCTION}

Inflammatory response is known to be a defense against external harmful factors, such as microbial pathogens and chemicals. However, an excessive inflammatory response

*Corresponding authors. Soo Young Choi, Tel: +82-33-248-2112; Fax: +82-33-248-3202; E-mail: sychoi@hallym.ac.kr; Won Sik Eum, Tel: +82-33-248-3221; Fax: +82-33-248-3202; E-mail: wseum@ hallym.ac.kr

${ }^{\text {"}}$ These authors contributed equally to this work.

https://doi.org/10.5483/BMBRep.2020.53.2.180

Received 15 July 2019, Revised 26 July 2019, Accepted 28 August 2019

Keywords: Inflammation, MAPK, NF-kB, PEP-1-GLRX1, Protein therapy contributes to various disorders, including cardiovascular diseases, cancer, arthritis, and neuronal diseases $(1,2)$. It is well known that macrophages, which are important immune cells, regulate the inflammatory response and produce pro-inflammatory mediators and cytokines. These mediators and cytokines contribute to the pathogenesis of inflammation (3-6). Therefore, Gue et al. (2016) suggest that inhibition of pro-inflammatory mediators and cytokines is important for preventing the progression of inflammatory diseases (7).

Nuclear factor-kappaB (NF-kB) is well known to modulate the inflammatory response. NF- $\mathrm{BB}$ is located in the cytoplasm as a complex with $\mathrm{I} \mathrm{KB}$ under normal conditions. However, $\mathrm{NF}-\kappa \mathrm{B}$ is translocated to the nucleus under $\mathrm{I} \mathrm{\kappa} B$ degradation when exposed to inflammatory stimuli, such as LPS (8). Also, other studies have shown that NF-kB is an essential pathway associated with pro-inflammatory mediator production in the inflammatory response $(9,10)$. In addition, mitogen-activated protein kinase (MAPK) has been considered to be a typical molecular target for the development of anti-inflammatory agents. Several studies have reported that the activation of MAPKs leads to increased production of the pro-inflammatory mediators. Therefore, NF- $\mathrm{KB}$ and MAPKs signaling pathways have been considered to be potential targets for antiinflammatory drugs $(9,11-13)$.

Human glutaredoxin (GLRX) is a small molecular-weight protein and a member of the thioredoxin family. In humans, GLRX1 is located in the cytosol, whereas GLRX2 is located in the mitochondria (14). Several studies have described GLRX1 as being distributed in various tissues and as regulating redox-dependent signaling pathways. GLRX1 has a protective role against oxidative stress (15-17). Also, Cater et al. (2014) have shown that GLRX1 plays an important role as an antioxidant protein and protects against copper-induced toxicity and neuronal cell death (18). We also have reported that PEP-1-GLRX1 markedly protects against hippocampal neuronal cell damage by inhibiting oxidative stress (19). In this study, we investigated the function of PEP-1-GLRX1 against

ISSN: 1976-670X (electronic edition)

Copyright (C) 2020 by the The Korean Society for Biochemistry and Molecular Biology

(c) This is an open-access article distributed under the terms of the Creative Commons Attribution Non-Commercial License (http://creativecommons.org/licenses/by-nc/4.0) which permits unrestricted non-commercial use, distribution, and reproduction in any medium, provided the original work is properly cited. 
inflammatory responses in vitro and in vivo.

\section{RESULTS AND DISCUSSION}

\section{Transduction of PEP-1-GLRX1 into Raw 264.7 cells}

PTDs including PEP-1 peptide are known to be small peptides that can transduce the plasma membrane either alone or combined with various macromolecules, such as proteins (20). PEP-1-GLRX1 protein was produced as described previously (19). Purified PEP-1-GLRX1 was confirmed through SDS-PAGE and Western blotting with a histidine antibody (Fig. 1A). Next, we measured the transduction efficiency of purified protein into Raw 264.7 cells. Figs. 1B-1D show that PEP-1-GLRX1 concentration- and timedependently transduced into the cells. Transduced PEP-1-GLRX1 levels remained for up to a maximum of $9 \mathrm{~h}$. We have also reported that this protein was transduced into HT-22 cells (19). However, the transduced levels of this protein into HT-22 cells remained longer than in Raw 264.7 cells.

\section{Effect of PEP-1-GLRX1 on expression of COX-2 and iNOS}

Since protein transduction is important for the development of therapeutic proteins, PTD-fused protein transduction can be used for the intracellular application of therapeutic proteins (20-24). In previous studies, we have demonstrated that PTD-fusion proteins were transduced into various cells (25-30). In this study, we first identified the distribution of transduced PEP-1-GLRX1 using fluorescence analysis. Green fluorescence signals were strongly observed in the cells treated with PEP-1-GLRX1, whereas cell treated with control GLRX1 did not show the fluorescence signals

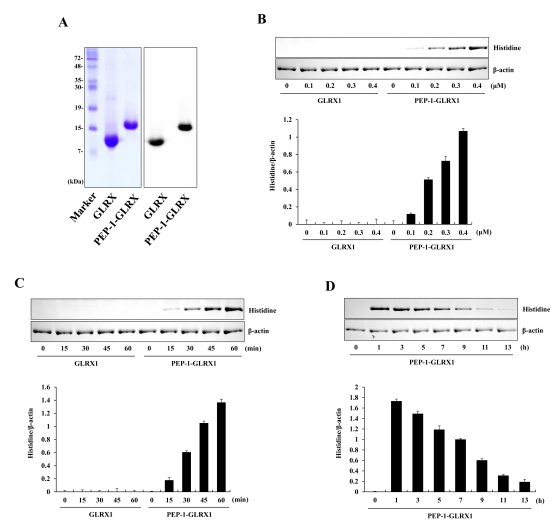

Fig. 1. Purification and transduction of PEP-1-GLRX1 protein into Raw 264.7 cells. Purified PEP-1-GLRX1 and control GLRX1 proteins were confirmed by $15 \%$ SDS-PAGE and Western blot analysis (A). Transduction of PEP-1-GLRX1 proteins into Raw 264.7 cells. PEP-1-GLRX1 protein $(0.1-0.4 \mu \mathrm{M})$ was added to the culture media for $1 \mathrm{~h}(\mathrm{~B})$, PEP-1-GLRX1 protein $(0.4 \mu \mathrm{M})$ was added to the culture media for $15-60 \mathrm{~min}(\mathrm{C})$. The stability of transduced PEP-1-GLRX1 protein was assessed after various time periods. The cells were treated with PEP-1-GLRX1 protein $(0.4 \mu \mathrm{M})$, incubated with $1-13 \mathrm{~h}$, and analyzed by Western blot analysis (D). The band intensities were measured by densitometer. The data are presented as mean values $\pm \operatorname{SD}(n=3)$.
(Fig. 2A). Next, to identify the location of transduced PEP-1GLRX1, we prepared nuclear and cytosolic fractions from the cells and did Western blotting using subcellular specific marker antibodies. Fig. 2B shows that transduced PEP-1-GLRX1 was distributed into the cytosol and nuclei of the cells.

To find out whether PEP-1-GLRX1 has anti-inflammatory roles against LPS-exposed Raw 264.7 cells, we examined the expression of COX-2 and iNOS levels. Treatment with LPS markedly increased COX-2 and iNOS expressions levels more than did those in the control. PEP-1-GLRX1 treatment significantly reduced the COX-2 and iNOS expression levels in the LPS-treated cells (Fig. 2C). These results suggest that transduced PEP-1-GLRX1 has anti-inflammatory effects by inhibiting pro-inflammatory mediators. Chung et al. (2010) showed that pro-inflammatory mediators increased in GLRX1 knockout mice more than in wild-type mice in a cigarette smoke-induced lung inflammation model, suggesting that the GLRX1 plays an important role in lung inflammation (31). In addition, other studies have shown that a pro-inflammatory response was increased in the lens and heart of GLRX1-deficient mice $(32,33)$. On the other hand, Aesif et al. (2011) reported that ablation of the GLRX1 protein attenuates LPS-induced proinflammatory responses by controlling S-glutathionylationsensitive signaling pathways, suggesting that GLRX1 expression is critical for activating alveolar macrophages in an LPS-induced lung inflammation mice model (34).
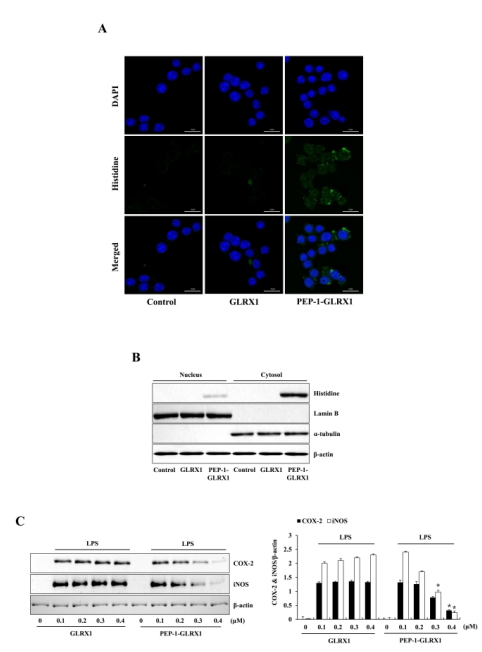

Fig. 2. Effects of transduced PEP-1-GLRX1 protein on LPS-induced inflammatory response in Raw 264.7 cells. The cells were treated with PEP-1-GLRX1 protein $(0.4 \mu \mathrm{M})$ for $1 \mathrm{~h}$, and the cellular distribution of transduced PEP-1-GLRX1 protein was confirmed by fluorescence microscopy (A). Scale bar $=50 \mu \mathrm{m}$. Subcellular localization of PEP1-GLRX1 (B). The nuclear and cytosolic extracts were prepared from transduced and normal Raw 264.7 cells and analyzed by Western blotting. The cells were pretreated with PEP-1-GLRX1 protein $(0.4 \mu \mathrm{M})$ for $1 \mathrm{~h}$ and then treated with LPS $(1 \mu \mathrm{g} / \mathrm{ml})$. Expression levels of COX-2 and iNOS protein were measured by Western blot analysis (C). The band intensity was measured by densitometer. The data are presented as mean values $\pm S D(n=3)$. $* P<0.01$ compared with LPS-treated cells. 


\section{Effect of PEP-1-GLRX1 on the NF- $\kappa B$ and MAPK signaling pathways}

$\mathrm{NF}-\mathrm{KB}$ and MAPK signaling pathway promote the production of pro-inflammatory mediators. NF- $\kappa \mathrm{B}$ is one of the key transcription factors that control gene expression of pro-inflammatory mediators and cytokines $(35,36)$. Also, MAPK signaling pathways (ERK, p38, JNK) are crucial for NF- $\mathrm{kB}$ activation and regulate the inflammatory response $(37,38)$. Therefore, we measured the effects of PEP-1-GLRX1 against LPS-induced phosphorylation of NF-KB and MAPKs in Raw 264.7 cells. In the LPS-treated cells, phosphorylated NF-kB and MAPKs expression levels were increased more than in the control. In contrast, PEP-1-GLRX1 significantly reduced phosphorylated NF- $\mathrm{KB}$ and MAPKs expression levels more than in the LPS-treated cells. Control GLRX1 did not alter phosphorylated NF- $\mathrm{KB}$ and MAPKs expression levels (Fig. 3). These results suggest that transduced PEP-1-GLRX1 inhibits inflammatory responses by regulating NF-אB and MAPKs signaling pathways. In agreement with our results, Ryu et al. (2018) have reported that transduced PEP-1-GLRX1 inhibited phosphorylation of MAPK signaling in $\mathrm{H}_{2} \mathrm{O}_{2}$-exposed $\mathrm{HT}$-22 cells (19). Other studies have reported that phosphorylated IкB $\alpha$ and p-65 protein expression levels were markedly increased in cigarette-smoke-induced lung inflammation GLRX1 knockout mice (31). In addition, several studies have reported that the phosphorylated NF- $\mathrm{KB}$ and MAPKs expression levels were increased in LPS-treated macrophages (39-41). In contrast, overexpression of GLRX1 decreased S-glutathionylation IKK $\beta$ Cys179 and increased NF-kB activation after oxidation induced by oxidative stress, suggesting that cellular content of GLRX1 regulates the activation of NF-kB under oxidative stress (42). Also, other studies have demonstrated that the cellular content of GLRX1 is regulated by the proinflammatory stimuli. GLRX1 level was increased in bronchial epithelial cells of in mice with allergic airway inflammation, activation of NF- $\mathrm{KB}$ and GLRX1 is also increased concomitant with activation of $\mathrm{NF}-\kappa \mathrm{B}$ in the retinal glial

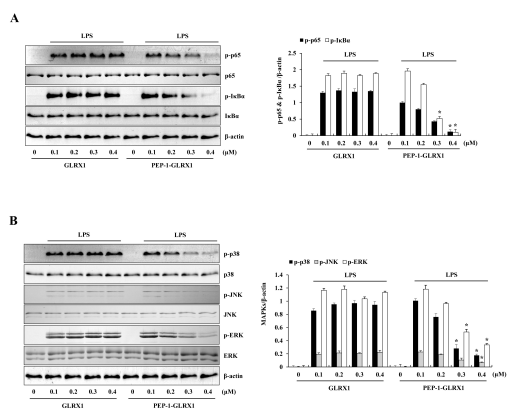

Fig. 3. Effects of transduced PEP-1-GLRX1 protein on LPS-induced NF- $\kappa B$ and MAPK phosphorylation in Raw 264.7 cells. The cells were pretreated with PEP-1-GLRX1 protein $(0.4 \mu \mathrm{M})$ for $1 \mathrm{~h}$ and then treated with LPS $(1 \mu \mathrm{g} / \mathrm{ml})$. Phosphorylation of NF- $\mathrm{kB}(\mathrm{A})$ and MAPK (B) levels was measured by Western blot analysis. The band intensity was measured by densitometer. The data are presented as mean values \pm SD $(n=3)$. ${ }^{*} P<0.01$ compared with LPS-treated cells. cells (43-45). Therefore, these findings suggest that NF-кB and GLRX1 may be regulated in a coordinated fashion. However, the role of GLRX1 in regulation of NF- $\kappa B$ signaling is not completely understood yet. Further studies are needed.

\section{Effect of PEP-1-GLRX1 on mouse-ear edema}

PTDs can effectively transduce exogenous macromolecules into cells and tissues (46). TPA is known as an inducer of skin inflammation, and several studies have used it to find out the effects of different treatments against skin inflammation (47-50). Therefore, we wanted to find out whether PEP-1-GLRX1 was transduced into mice ear tissue and whether it demonstrated protective effects against TPA-induced edema. After mice ears were treated with PEP-1-GLRX and TPA as described in Methods, we confirmed PEP-1-GLRX1 levels using immunohistochemical analysis. As shown in Fig. 4A, there were no changes in the His antibody staining in the control-, TPA-, and TPA + control GLRX1-treated groups. However, fluorescent signals were markedly increased in the PEP-1-GLRX1-treated groups compared to that in the control and other groups.

Further, we measured the effects of PEP-1-GLRX1 against TPA-induced mouse-ear edema. As shown in Fig. 4B, TPA-treated mice showed markedly increased ear thickness and weights compared to those in the control mice. PEP-1-GLRX1 drastically reduced ear thickness and weights more than in TPA-treated mice. However, there were no significant changes in the control GLRX1-treated mice compared to the TPA-treated mice. In addition, PEP-1-GLRX1 drastically reduced infiltration of monocytes, which is an early event in skin inflammation. Control

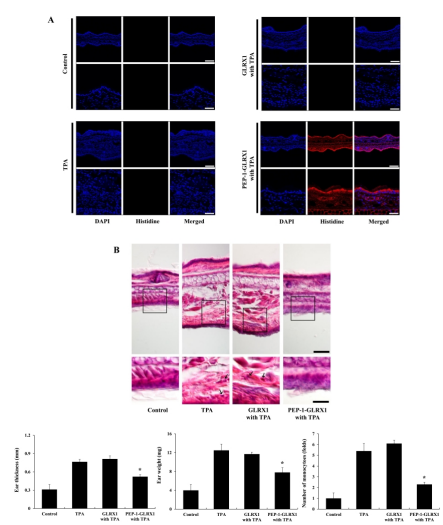

Fig. 4. Effects of PEP-1-GLRX1 protein on ear edema in a TPA-induced mice model of inflammation. Ears of mice were exposed to TPA (1 $\mu \mathrm{g} / \mathrm{ear})$, and PEP-1-GLRX1 protein $(10 \mu \mathrm{g})$ was topically applied to mice ears $1 \mathrm{~h}$ after TPA treatment for 3 days. Transduced PEP-1-GLRX1 protein was confirmed by Histidine antibody (A). Scale bar $=50 \mu \mathrm{m}$ (top panel) and $25 \mu \mathrm{m}$ (bottom panel). The effects of PEP-1-GLRX1 protein against TPA-induced ear edema was analyzed by hematoxylin and eosin immunostaining, changes of ear thickness and ear weights, and monocyte infiltration folds (B). Scale bar $=50 \mu \mathrm{m}$ (top panel) and $25 \mu \mathrm{m}$ (bottom panel). ${ }^{*} P<0.01$ compared with TPA-treated mice. The data are presented as mean values \pm SD $(n=5)$. 
GLRX had a minimal effect. These results indicate that PEP-1-GLRX1 plays an anti-inflammatory role in TPA-induced skin inflammation. We have demonstrated that cell-permeable antioxidant PTD-fusion protein markedly inhibits TPA-induced inflammation in a mice model $(27,48)$. In addition, other studies have reported that antioxidant proteins play protective roles in inflammation $(51,52)$. However, the exact function of GLRX1 in inflammation requires further study.

In summary, we have demonstrated that transduced PEP-1GLRX1 markedly inhibits inflammation in vitro and in vivo by the reduction of inflammatory responses. Therefore, we suggest that PEP-1-GLRX1 may have applications in inflammatory disorders.

\section{MATERIALS AND METHODS}

\section{Materials and cell culture}

We obtained PEP-1-GLRX1 and control GLRX1 protein were prepared as described previously (19). Histidine, COX-2, iNOS,

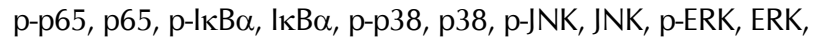
and $\beta$-actin antibodies from Santa Cruz Biotechnology (Santa Cruz, CA, USA) and Cell Signaling Technology (Beverly, MA, USA). LPS and TPA was purchased from Sigma-Aldrich (St. Louis, MO, USA). We obtained male ICR mice (4-6 weeks old) from the Experimental Animal Center at Hallym University. All other agents were of the highest grade available unless otherwise stated.

Raw 264.7 murine macrophage cells were cultured in Dulbecco's modified Eagle's medium (DMEM) containing $20 \mathrm{mM}$ HEPES/ $\mathrm{NaOH}(p \mathrm{H} 7.4), 5 \mathrm{mM} \mathrm{NaHCO}, 10 \%$ fetal bovine serum (FBS) and antibiotics (100 $\mu \mathrm{g} / \mathrm{ml}$ streptomycin, $100 \mathrm{U} / \mathrm{ml}$ penicillin) at $37^{\circ} \mathrm{C}$ under humidified conditions of $95 \%$ air and $5 \% \mathrm{CO}_{2}$.

\section{Purification and transduction of PEP-1-GLRX1 protein}

PEP-1-GLRX1 and control GLRX1 proteins were purified as described previously (19). To remove endotoxins from purified proteins, we treated the proteins with Detoxi-Gel ${ }^{\mathrm{TM}}$ (Pierce, Rockford, IL, USA) according to the manufacturer's instruction and confirmed the proteins $(<0.03 \mathrm{EU} / \mathrm{ml})$ using a Limulus amoebocyte lysate assay (BioWhitaker, Walkersville, MD, USA) $(27,48)$. Then, the protein concentration was measured using the Bradford assay (53).

To detect the transduction of PEP-1-GLRX1, we treated Raw 26.7 cells with various concentrations of PEP-1-GLRX1 and control GLRX1 $(0.1-0.4 \mu \mathrm{M})$ for $1 \mathrm{~h}$. Also, the cells were treated with PEP-1-GLRX1 and control GLRX1 (0.4 $\mu \mathrm{M})$ for various times (15-60 $\mathrm{min})$. Then the cells were treated with trypsin-EDTA, washed with phosphate-buffered saline (PBS), and harvested for Western blot analysis.

\section{Western blot analysis}

We did Western blot analysis as described previously $(27,48)$. Equal amounts of sample proteins were separated with 15\% SDS-PAGE and transferred to a nitrocellulose membrane, which was blocked with $5 \%$ nonfat dry milk in TBST buffer $(25 \mathrm{mM}$ Tris- $\mathrm{HCl}, 140 \mathrm{mM} \mathrm{NaCl}, 0.1 \%$ Tween 20, $\mathrm{pH}$ 7.5) for $1 \mathrm{~h}$. The membranes were immunoblotted with the indicated primary and HRP-conjugated secondary antibodies as recommended by the manufacturer. The protein bands were detected using enhanced chemiluminescent reagents (Amersham, Franklin Lakes, NJ, USA).

\section{Fluorescence microscopy analysis}

Fluorescence microscopy analysis was done as described previously $(27,48)$. Raw 264.7 cells were grown on coverslips and treated with $0.4 \mu \mathrm{M}$ of PEP-1-GLRX 1 for $1 \mathrm{~h}$ at $37^{\circ} \mathrm{C}$. Then, the cells were washed twice with PBS and fixed with $4 \%$ paraformaldehyde for $5 \mathrm{~min}$ at room temperature. Then the cells were permeabilized and blocked for 40 min with 3\% bovine serum albumin, $0.1 \%$ Triton X-100 in PBS (PBS-BT) and washed with PBS-BT. The primary antibody (Histidine) was diluted 1:2000 and incubated for $1 \mathrm{~h}$ at room temperature. The secondary antibody (Alexa Fluor 488, Invitrogen) was diluted 1:15000 and incubated for $1 \mathrm{~h}$ at room temperature in the dark. Nuclei were stained for $2 \mathrm{~min}$ with $1 \mu \mathrm{g} / \mathrm{ml}$ DAPI (Roche, Mannheim, Germany). We analyzed the distributions of fluorescence using a fluorescence microscope (Nikon Eclipse 80i; Nikon, Tokyo, Japan).

\section{Subcellular fractionation of the transduced cells}

The nuclear and cytosolic fractions were prepared as previously described (54). Transduced Raw 264.7 cells were washed with PBS, acid-washed with $0.2 \mathrm{M}$ glycine- $\mathrm{HCl}, \mathrm{pH} 2.2$, and trypsinized for $10 \mathrm{~min}$ at $37^{\circ} \mathrm{C}$. The cells were harvested after washing with cold PBS and pelleted. The cells were then resuspended in $1 \mathrm{ml}$ of NP-40 buffer by gentle pipetting and incubated on ice for 10 $\min$. Cells were spun through a sucrose cushion at $1000 \mathrm{~g}$ for 10 $\mathrm{min}$, and the cytosolic fractions were collected from the supernatants. Pellets were washed with $1 \mathrm{ml}$ of NP-40 buffer to completely remove cytosolic fractions. The nuclei were lysed in a lysis buffer (50 mM Tris- $\mathrm{HCl}, \mathrm{pH} 8.0,150 \mathrm{mM} \mathrm{NaCl}, 0.02 \%$ sodium azide, $100 \mu \mathrm{g} / \mathrm{ml}$ PMSF, $1 \%$ Triton X-100). The resulting nuclear and cytosolic lysates were analyzed by Western blotting.

\section{TPA-induced mouse ear edema model}

Male ICR mice were housed at a constant temperature $\left(23^{\circ} \mathrm{C}\right)$ and relative humidity $(60 \%)$ with a fixed $12 \mathrm{~h}$ light: $12 \mathrm{~h}$ dark cycle and had free access to food and water. All experimental procedures involving animals and their care conformed to the Guide for the Care and Use of Laboratory Animals of the National Veterinary Research and Quarantine Service of Korea and were approved by the Hallym Medical Center Institutional Animal Care and Use Committee.

TPA-induced mouse-ear edema models were prepared as described previously $(27,48)$. To examine the effects of PEP-1-GLRX1 against TPA-induced ear edema, we divided the mice into four groups ( $n=5$ per group). The experimental groups were as follows: (1) normal control mice; (2) TPA-induced ear-edema mice; (3) TPA + control GLRX1-treated mice; and (4) TPA + PEP-1-GLRX1-treated mice. TPA $(1.0 \mu \mathrm{g})$ dissolved in 20 $\mu$ of acetone was applied to the inner and outer surfaces of the ears of the mice every day for 3 days. PEP-1-GLRX1 (10 $\mu \mathrm{g})$ protein 
was topically applied to the ears of mice every day $1 \mathrm{~h}$ after TPA treatment. After the final treatment with TPA and PEP-1-GLRX1, we sacrificed the mice to obtain ear biopsies . Ear thicknesses were measured using a digital thickness gauge (Mitutoyo Corporation, Toyko, Japan). Ear weights were measured after 5-mm diameter ear biopsies were obtained from each group using a punch (Kai Industries, Gifu, Japan). For histological analysis, ear biopsies were fixed in $4 \%$ paraformaldehyde, embedded in paraffin, sectioned at a thickness of $5 \mu \mathrm{m}$, and then stained with Histidine and hematoxylin and eosin.

\section{Statistical analysis}

Data represent the mean of three experiments \pm SD. Differences between groups were analyzed by one-way analysis of variance followed by a Bonferroni's post-hoc test using GraphPad Prism software (version 5.01; GraphPad Software Inc., San Diego, CA, USA); $\mathrm{P}<0.05$ was considered to indicate a statistically significant difference.

\section{ACKNOWLEDGEMENTS}

This research was supported by the Bio \& Medical Technology Development Program of the National Research Foundation (NRF) funded by the Korean government (MSIT) (2018M3A 9C8023568).

\section{CONFLICTS OF INTEREST}

The authors have no conflicting interests.

\section{REFERENCES}

1. Medzhitov R (2008) Origin and physiological roles of inflammation. Nature 454, 428-435

2. Tsaryk R, Peters K, Barth S, Unger RE, Schamweber D and Kirkpatrick CJ (2013) The role of oxidative stress in pro-inflammatory activation of human endothelial cells on Ti6A14V alloy. Biomaterials 34, 8075-8085

3. Fujiwara $N$ and Kobayashi $K$ (2005) Macrophages in inflammation. Curr Drug Targets Inflamm Allergy 4, 281-286

4. Hiraiwa K and van Eeden SF (2013) Contribution of lung macrophages to the inflammatory responses induced by exposure to air pollutants. Mediators Inflamm 2013, 619523

5. Jin SE, Kim OS, Yoo SR et al (2016) Anti-inflammatory effect and action mechanisms of traditional herbal formula Gamisoyo-san in RAW 264.7 macrophages. BMC Complement Altern Med 16, 219

6. Shen YZ, Sun Z and Guo X (2015) Citral inhibits lipopolysaccharide-induced acute lung injury by activating PPAR-gamma. Eur J Pharmacol 747, 45-51

7. Guo C, Yang L, Luo J et al (2016) Sophoraflavanone G from Sophora alopecuroides inhibits lipopolysaccharide-induced RAW 264.7 cells by targeting PI3K/Akt, JAK/STAT and Nrf2/HO-1 pathways. Int Immunopharmacol 38, 349-356

8. Ducut Sigala JL, Bottero V, Young DB, Shevchenko A, Mercurio M and Verma IM (2004) Activation of transcription factor NF-kappaB requires ELKS, an IkappaB kinase regulatory subunit. Science 304, 1963-1967

9. Wang Y, Cui Y, Cao F, Qin Y, Li W and Zhang J (2015) Gangliosdie GD 1a suppresses LPS-induced pro-inflammatory cytokines in RAW 264.7 macrophages by reducing MAPKs and NF-kappaB signaling pathways through TLR4. Int Immunopharmacol 28, 136-145

10. Li MY, Sun L, Niu XT et al (2018) Astaxanthin protects lipopolysaccharide-induced inflammatory response in Channa argus through inhibiting NF- $\mathrm{KB}$ and MAPKs signaling pathways. Fish Shellfish Immunol 86, 280-286

11. Haque MA, Jantan I and Harikrishnan H (2018) Zerumbone suppresses the activation of inflammatory mediators in LPS-stimulated U937 macrophages through MyD88-dependent NF-кB/MAPK/PI3K-Akt signaling pathways. Int Immunopharmacol 55, 312-322

12. Arthur JS and Ley SC (2013) Mitogen-activated protein kinases in innate immunity. Nat Rev Immunol 13, 679-692

13. Hwang PA, Chien SY, Chan YL et al (2011) Inhibition of lipopolysaccharide (LPS)-induced inflammatory responses by Sargassum hemiphyllum sulfated polysaccharide extract in RAW 264.7 macrophage cells. J Agric Food Chem 59, 2062-2068

14. Lillig $\mathrm{CH}$, Berndt $\mathrm{C}$ and Holmgren $\mathrm{A}$ (2008) Glutaredoxin systems. Biochim Biophys Acta 1780, 1304-1317

15. Okuda M, Inoue N, Azumi H et al (2001) Expression of glutaredoxin in human coronary arteries: its potential role in antioxidant protection against atherosclerosis. Arterioscler Thromb Vasc Biol 21, 1483-1487

16. Pai HV, Starke DW, Lesnefsky EJ, Hoppel CL and Mieyal JJ (2007) What is the functional significance of the unique location of glutaredoxin 1 (GRx1) in the intermembrane space of mitochondria? Antioxid Redox Signal 9, 2027-2033

17. Peltoniemi M, Kaarteenaho-Wiik R, Saily M et al (2004) Expression of glutaredoxin is highly cell specific in human lung and is decreased by transforming growth factor-beta in vitro and in interstitial lung diseases in vivo. Hum Pathol 35, 1000-1007

18. Cater MA, Materia S, Xiao Z et al (2014) Glutaredoxin1 protects neuronal cells from copper-induced toxicity. Biometals 27, 661-672

19. Ryu EJ, Kim DW, Shin MJ et al (2018) PEP-1-glutaredoxin 1 protects against hippocampal neuronal cell damage from oxidative stress via regulation of MAPK and apoptotic signaling pathways. Mol Med Rep 18, 2216-2228

20. Joliot A and Prochiantz A (2004) Transduction peptides: from technology to physiology. Nat Cell Biol 6, 189-196

21. Dolgova NV, Nokhrin S, Yu CH, George GN and Dmitriev OY (2013) Copper chaperone Atox1 interacts with the metal-binding domain of Wilson's disease protein in cisplatin detoxification. Biochem J 454, 147-156

22. Wadia JS and Dowdy SF (2002) Protein transduction technology. Curr Opin Biotechnol 13, 52-56

23. van den Berg A and Dowdy SF (2011) Protein transduction domain delivery of therapeutic macromolecules. Curr Opin Biotechnol 22, 888-893

24. Morris MC, Depollier J, Mery J, Heitz F and Divita G (2001) A peptide carrier for the delivery of biologically active proteins into mammalian cells. Nat Biotechonol 19, 1173-1176 
25. Yeo HJ, Yeo EJ, Shin MJ et al (2018) Protective effects of Tat-DJ-1 protein against streptozotocin-induced diabetes in a mice model. BMB Rep 51, 362-367

26. Yeo HJ, Shin MJ, Yeo EJ et al (2019) Tat-CIAPIN1 inhibits hippocampal neuronal cell damage through the MAPK and apoptotic signaling pathways. Free Radic Biol Med 135, 68-78

27. Kim DW, Shin MJ, Choi YJ et al (2018) Tat-ATOX1 inhibits inflammatory responses via regulation of MAPK and NF- $\mathrm{KB}$ pathways. BMB Rep 51, 654-659

28. Kim MJ, Park M, Kim DW et al (2015) Transduced PEP-1-PON1 proteins regulate microglial activation and dopaminergic neuronal death in a Parkinson's disease model. Biomaterials 64, 45-56

29. Kim YN, Jung HY, Eum WS et al (2014) Neuroprotective effects of PEP-1-carbonyl reductase 1 against oxidativestress-induced ischemic neuronal cell damage. Free Radic Biol Med 69, 181-196

30. Lee SJ, Kang HK, Choi YJ et al (2018) PEP-1-paraoxonase 1 fusion protein prevents cytokine-induced cell destruction and impared insulin secretion in rat insulinoma cells. BMB Rep 51, 538-543

31. Chung S, Sunder IK, Yao H, Ho YS and Rahman I (2010) Glutaredoxin 1 regulates cigarette smoke-mediated lung inflammation through differential modulation of $\mathrm{I}_{\mathrm{K}} \mathrm{B}$ kinases in mice: impact on histone acetylation. Am J Physiol Lung Cell Mol Physiiol 299, L192-L203

32. Malik G, Nagy N, Ho YS, Maulik N and Das DK (2008) Role of glutaredoxin-1 in cardioprotection: an insight with Glrx1 transgenic and knockout animals. J Mol Cell Cardiol 44, 261-269

33. Meyer LM, Lofgren S, Ho YS et al (2009) Absence of glutaredoxn 1 increase lens susceptibility to oxidative stress induced by UVR-B. Exp Eye Res 89, 833-839

34. Aesif SW, Anathy V, Kuipers I et al (2011) Ablation of glutaredoxin-1 attenuates lipopolysaccharide-induced lung inflammation and alveolar macrophage activation. Am J Respir Cell Mol Biol 44, 491-499

35. Shi Q, Cao J, Fang L et al (2014) Geniposde suppresses LPS-induced nitric oxide, PGE2 and inflammatory cytokine by downregulating NF-kappaB, MAPK and AP-1 signaling pathways in macrophages. Int Immunopharmacol 20, 298-306

36. Chen H, Sohn J, Zhang L, Tian J, Chen S and Bjeldanes LF (2014) Anti-inflammatory effects of chicanine on murine macrophage by down-regulating LPS-induced inflammatory cytokines in IkappaBalpha/MAPK/ERK signaling pathways. Eur J Pharmacol 724, 168-174

37. Yodkeeree S, Ooppachai C, Pompimon W and Limtrakul $P$ (2018) O-methybulbocapnine and dicentrine suppress LPS-induced inflammatory responses by blocking NF-kB and AP-1 inactivation through inhibition MAPKs and Akt signaling in RAW264.7 macrophages. Biol Pharm Bull 41, 1219-1227

38. Plotnikov A, Zehorai E, Procaccia S and Seger R (2011) The MAPK cascades: signaling components, nuclear roles and mechanisms of nuclear translocation. Biochim Biophys Acta 1813, 1619-1633

39. Qiang Z, Ko CH, Siu WS et al (2018) Inhibitory effect of different Dendrobium species on LPS-induced inflammation in macrophages via suppression of MAPK pathways. Chin J Nat Med 16, 481-489

40. Harikrishnan H, Jantan I, Haque MA and Kumolosasi E (2018) Anti-inflammatory effect of phyllanthus amarus Schum. \& Thonn. Through inhibition of NF-kB, MAPK, and PI3K-Akt signaling pathways in LPS-induced human macrophages. BMC Complement Altern Med 18, 224

41. Islam SU, Lee JH, Shehzad A, Ahn EM, Lee YM and Lee YS (2018) Decursinol angelate inhibits LPS-induced macrophages polarization through modulation of the NF- $\mathrm{KB}$ and MAPK signaling pathways. Molecules 23, 1880

42. Reynaert NL, van der Vliet A, Gulal AS et al (2006) Dynamic redox control of NF-kappaB through glutaredoxin-regulated S-glutathionylation of inhibitory kappaB kinase beta. Proc Natl Acad Sci U S A 103, 13086-13091

43. Reynaert NL, Wouters EF and Janssen-Heininger YM (2007) Modulation of glutaredoxin-1 expression in a mouse model of allergic airway disease. Am J Respir Cell Mol Biol 36, 147-151

44. Poynter ME, Irvin CG and Janssen-Heininger YM (2002) Rapid activation of nuclear factor-kappaB in airway epithelium in a murine model of allergic airway inflammation. Am J Pathol $160,1325-1334$

45. Shelton MD, Distler AM, Kern TS and Mieyal JJ (2009) Glutaredoxin regulates autocrine and paracrine proinflammatory responses in retinal glial (Muller) cells. J Biol Chem 284, 4760-4766

46. El-Andaloussi S, Holm T and Langel U (2005) Cell-penetrating peptides: mechanisms and applications. Curr Pharm Des 11, 3597-3611

47. Stanley PL, Steiner S, Havens M and Tramposch KM (1991) Mouse skin inflammation induced by multiple topical applications of 12-O-tetradecanoyl phorbol-13-acetate. Skin Pharmacol 4, 262-271

48. Kim MJ, Jeong HJ, Kim DW et al (2014) PEP-1-PON1 protein regulates inflammatory response in raw 264.7 macrophages and ameliorates inflammation in a TPA-induced animal model. PLoS One 9, e86034

49. Park MK, Cho SA, Lee HJ et al (2012) Suppression of transglutaminase-2 involved in anti-inflammatory actions of glutasamine in 12-O-tetradecanoyl phorbol-13-acetateinduced skin inflammation. Biomol Ther 20, 380-385

50. Kulkarni NM, Muley MM, Jaji MS et al (2015) Topical atorvastatin ameliorates 12-O-tetradecanoylphorbol-13acetate induced skin inflammation by reducing cutaneous cytokine levels and NF-kB activation. Arch Pharm Res 28, 1238-1247

51. Kamiya T, Takeuchi K, Fukudome S, Hara H and Adachi T (2018) Copper chaperone antixodiant-1, Atox-1, is involved in the induction of SOD3 in THP-1 cells. Biometals 31, 61-68

52. Kim SH, Kim MO, Gao P et al (2005) Overexpression of extracellular superoxide dismutase (EC-SOD) in mouse skin plays a protective role in DMBA/TPA-induced tumor formation. Oncol Res 15, 333-341

53. Bradford M (1976) A rapid and sensitive method for the quantitation of microgram quantities utilizing the principle of protein-dye binding. Anal Biochem 72, 248-254

54. Ahn EH, Kim DW, Shin MJ et al (2014) PEP-1-PEA-15 protects against toxin-induced neuronal damage in a mouse model of Parkinson's disease. Biochim Biophys Acta 1840, 1686-1700 